\section{International Scientific Journal Theoretical \& Applied Science}

p-ISSN: 2308-4944 (print) e-ISSN: 2409-0085 (online)

Year: 2017 Issue: $06 \quad$ Volume: 50

Published: $24.06 .2017 \quad$ http://T-Science.org

\section{Denis Chemezov}

Master of Engineering and Technology, Corresponding Member of International Academy of Theoretical and Applied Sciences, Lecturer of Vladimir Industrial College, Russian Federation chemezov-da@yandex.ru

SECTION 6. Metallurgy and energy.

\title{
SHRINKAGE OF SOME METAL ALLOYS AFTER SOLIDIFICATION
}

Abstract: The calculated values of shrinkage of the metal ingots of the circular cross section after solidification in the mould are presented in the article.

Key words: shrinkage, solidification, steel, cast iron, a casting.

Language: Russian

Citation: Chemezov D (2017) SHRINKAGE OF SOME METAL ALLOYS AFTER SOLIDIFICATION. ISJ Theoretical \& Applied Science, 06 (50): 87-89.

Soi: http://s-o-i.org/1.1/TAS-06-50-10 Doi: crossef https://dx.doi.org/10.15863/TAS.2017.06.50.10

\section{УСАДКА НЕКОТОРЫХ МЕТАЛЛИЧЕСКИХ СПЛАВОВ ПОСЛЕ ПРОЦЕССА ЗАТВЕРДЕВАНИЯ}

Аннотация: В статье представлены расчетные значения усадки металлических слитков круглого сечения после затвердевания в литейной форме.

Ключевые слова: усадка, затвердевание, сталь, чугун, отливка.

\section{Введение}

Усадка возникает во всех фазах материала (в жидком состоянии, при охлаждении и после затвердевания) из которого изготавливается отливка. Усадка представляет собой изменение (уменьшение) габаритных размеров отливок при их охлаждении [1]. На величину линейной или объемной усадки отливок, изготовленных из различных металлических сплавов, влияет ряд факторов, в том числе и процентное содержание легирующих элементов.

Компьютерное моделирование позволяет имитировать реальный процесс литья от заполнения расплавом литейной формы до полного затвердевания отливки с расчетом величины усадки. Преимуществом применения специальных компьютерных программ является высокая точность расчетов и возможность моделирования процесса литья любого сплава.

\section{Материалы и методы исследования}

Моделирование процесса литья слитков и последующий расчет усадки различных сплавов осуществлялись в компьютерной программе LVMFlow. Процесс литья слитков из различных металлических сплавов выполнялся при одинаковых условиях. В качестве материалов отливок принимались следующие сплавы:
1. Легированная сталь для отливок марки 20ГТЛ [2]. Химический состав сплава: железо $97.18 \%$, углерод - $0.22 \%$, кремний $-0.4 \%$, марганец $-1.2 \%$, хром - $0.2 \%$, фосфор и сера $0.04 \%$, медь - $0.5 \%$, никель - $0.2 \%$, титан - 0.02 $\%$. Порог текучести сплава - $70 \%$, порог протекания - $30 \%$.

2. Углеродистая сталь марки SS1505. Химический состав сплава: железо - $98.7 \%$, углерод $-0.25 \%$, кремний $-0.3 \%$, марганец -0.6 $\%$, хром $-0.01 \%$, фосфор $-0.03 \%$, сера $-0.02 \%$, медь - $0.07 \%$, молибден и никель - $0.01 \%$. Порог текучести и порог протекания сплава -70 $\%$.

3. Коррозионно-стойкая сталь марки 321 [3]. Химический состав сплава: железо - $69.75 \%$, никель $-9 \%$, хром - $18 \%$, кремний $-0.5 \%$, марганец $-1.5 \%$, углерод $-0.12 \%$, медь $-0.1 \%$, титан - $1 \%$, фосфор - $0.02 \%$, сера - $0.01 \%$. Порог текучести сплава -70 \%, порог протекания $-30 \%$.

4. Серый чугун марки EN-GJL-350 [4]. Химический состав сплава: железо - $94.7 \%$, углерод - $3 \%$, кремний $-1.3 \%$, марганец - $0.9 \%$, фосфор и сера $-0.05 \%$. Порог текучести сплава $50 \%$, порог протекания $-30 \%$.

5. Ковкий чугун с шаровидным графитом марки EN-GJS-500 [5]. Химический состав сплава: железо - 93.83 \%, углерод - $3.4 \%$, 
кремний $-2.4 \%$, марганец - $0.3 \%$, фосфор - 0.02 $\%$, сера - $0.01 \%$, магний $-0.04 \%$. Порог текучести сплава $-70 \%$, порог протекания - 30 $\%$.

6. Безоловянная бронза марки CC330G [6]. Химический состав сплава: медь - $90 \%$, алюминий $-9 \%$, железо - $0.5 \%$, марганец -0.1 $\%$, никель $-0.4 \%$. Порог текучести и протекания сплава $-30 \%$.

7. Свинцовая латунь марки С85700 [7]. Химический состав сплава: медь $-61.7 \%$, цинк $35 \%$, алюминий $-0.4 \%$, железо - $0.3 \%$, никель $0.6 \%$, олово и свинец - $1 \%$. Порог текучести и протекания сплава $-30 \%$.
8. Алюминиевый литейный сплав марки AISi12 [8]. Химический состав сплава: алюминий - $88.4 \%$, кремний - $11.2 \%$, марганец $-0.08 \%$, медь $-0.03 \%$, железо - $0.15 \%$, цинк $-0.05 \%$, титан $-0.09 \%$. Порог текучести сплава $-70 \%$, порог протекания $-30 \%$.

9. Цинковый сплав марки ZA-27 [9]. Химический состав сплава: цинк - $72.65 \%$, алюминий - $25 \%$, магний - $0.01 \%$, медь -2.25 $\%$, железо - $0.07 \%$, свинец и кадмий $-0.01 \%$. Порог текучести и протекания сплава $-30 \%$.

Начальные температуры каждого сплава до моделирования процесса литья слитков круглого сечения представлены в табл. 1 .

Начальные температуры расплавов.

Таблица 1

\begin{tabular}{|c|c|}
\hline Наименование сплава & Teмпература, $^{\circ} \mathbf{C}$ \\
\hline 20ГTЛ & 1600 \\
\hline SS1505 & 1610 \\
\hline 321 & 1540 \\
\hline EN-GJL-350 & 1340 \\
\hline EN-GJS-500 & 1290 \\
\hline CC330G & 1130 \\
\hline C85700 & 1010 \\
\hline AISi12 & 690 \\
\hline ZA-27 & 580 \\
\hline
\end{tabular}

Более точные результаты компьютерного моделирования были получены при учете конвекции и газа во время заполнения литейной формы расплавом. Начальное давление газа в литейной форме и давление газа снаружи литейной формы приняты величиной 1 бар.

\section{Результаты и их обсуждение}

В соответствии с выполненным расчетом отливка из литейного сплава марки AISi12 имеет наименьшую массу. Обозначим массу данной отливки $m_{a l .}$. (кг). Тогда расчетные массы отливок из других сплавов можно представить в следующем виде:

$2.9431 m_{a l}$ - для сплава марки 20ГТЛ;

$2.9431 m_{a l .}$ - для сплава марки SS1505;

$2.9649 m_{a l .}$ - для сплава марки 321 ;

$2.9934 m_{a l}$ - для сплава марки EN-GJL-350;

$2.8884 m_{a l}$ - для сплава марки EN-GJS-500;

$3.1903 m_{a l}$ - для сплава марки CC330G;

$3.3238 m_{a l .}$ - для сплава марки С85700;

$2.3041 m_{a l}$ - для сплава марки ZA-27.

Наименьшее время охлаждения определено для слитка, изготовленного из стали марки
SS1505. Обозначим время охлаждения данной отливки $t_{\text {cl.st. }}$ (c). Тогда расчетное время охлаждения отливок из других сплавов можно представить в следующем виде:

$1.1851 t_{\text {cl.st. }}$ - для сплава марки 20ГТЛ;

$1.2119 t_{\text {cl.st. }}$ - для сплава марки 321 ;

$2.7668 t_{\text {cl.st. }}$ - для сплава марки EN-GJL-350;

$2.642 t_{\text {cl.st. }}$ - для сплава марки EN-GJS-500;

$2.2272 t_{\text {cl.st. }}$ - для сплава марки CC330G;

$1.2971 t_{\text {cl.st. }}$ - для сплава марки C85700;

$2.2113 t_{\text {cl.st. }}$ - для сплава марки AISi12;

4.4114t $t_{\text {cl.st. }}$ - для сплава марки ZA-27.

Таким образом, можно сказать, что процесс охлаждения слитка из цинкового сплава марки ZA-27 наиболее продолжителен по сравнению с охлаждением слитков из других сплавов (с учетом одинаковой конфигурации выливаемых отливок).

Усадка наиболее выражена в тех слоях материала отливок, которые затвердевают в последнюю очередь.

Расчетные значения усадки слитков после затвердевания представлены в табл. 2. 


\begin{tabular}{|c|c|c|c|c|c|c|}
\hline Impact Factor: & $\begin{array}{l}\text { ISRA (India) } \\
\text { ISI (Dubai, UAE } \\
\text { GIF (Australia) } \\
\text { JIF }\end{array}$ & $\begin{array}{l}=1.344 \\
=0.829 \\
=0.564 \\
=1.500\end{array}$ & $\begin{array}{l}\text { SIS (USA) } \\
\text { PИНЦ (Russia) } \\
\text { ESJI (KZ) } \\
\text { SJIF (Morocco) }\end{array}$ & $\begin{array}{l}=0.912 \\
=0.234 \\
=3.860 \\
=\mathbf{2 . 0 3 1}\end{array}$ & $\begin{array}{l}\text { ICV (Poland) } \\
\text { PIF (India) } \\
\text { IBI (India) }\end{array}$ & $\begin{array}{l}=6.630 \\
=1.940 \\
=4.260\end{array}$ \\
\hline
\end{tabular}

Таблица 2

Усадка слитков после затвердевания.

\begin{tabular}{|c|c|}
\hline Наименование сплава & Усадка, \% \\
\hline 20ГТЛ & 3.37 \\
\hline SS1505 & 2.28 \\
\hline 321 & 3.19 \\
\hline EN-GJL-350 & 2.98 \\
\hline EN-GJS-500 & 1.82 \\
\hline CC330G & 2.61 \\
\hline C85700 & 3.23 \\
\hline AISi12 & 6.25 \\
\hline ZA-27 & 5.09 \\
\hline
\end{tabular}

Минимальное уменьшение объема после процесса затвердевания наблюдается у отливок, изготовленных из сплавов на основе железа (в частности ковкий чугун марки EN-GJS-500 и качественная углеродистая сталь марки SS1505). Максимальное уменьшение объема наблюдается у отливок, изготовленных из цветных сплавов (в частности алюминиевый литейный сплав марки AISi12 и цинковый сплав марки ZA-27).

Уменьшение усадки в чугунах достигается при изменении содержания таких легирующих элементов как углерод и марганец. Уменьшение усадки в сталях обуславливается малым процентным содержанием углерода (до $0.25 \%$ ). Снижение содержания марганца, хрома и особенно серы (вредная примесь) также способствует уменьшению усадочного явления. Высокое содержание алюминия в цветных сплавах приводит к увеличению усадки отливки. При увеличении содержания меди в сплаве наблюдается уменьшение усадки отливки после затвердевания.

\section{Заключение}

Таким образом, принимая во внимание полученные результаты моделирования, можно сделать следующие выводы:

1. Цинковый сплав марки ZA-27, имеющий в три раза меньшую температуру плавления, чем температура плавления углеродистой или легированной сталей рассмотренных марок, охлаждается медленно в литейной форме с минимальным образованием остаточных напряжений в слитке.

2. Алюминиевый литейный сплав марки AISi12 после затвердевания имеет наибольшую усадку. Данные расчетные значения позволяют выполнять проектирование необходимых размеров и конфигурации литейной оснастки с учетом изменения размеров отливки.

\section{References:}

1. (2017) Shrinkage of metals. Available: https://ru.wikipedia.org/wiki/Усадка_металлов (Accessed: 22.06.2017).

2. (2017) Steel 20ГТЛ. Available: http://www.1bm.ru/techdocs/alloys/materials/12 3/info/2717 (Accessed: 22.06.2017).

3. (2017) 321 Stainless Steel Technical Data Sheet. Available: http://www.metalshims.com/t-321-StainlessSteel-technical-data-sheet.aspx (Accessed: 22.06.2017).

4. (2017) EN-GJL-350 (EN-JL1060). Available: http://www.steelnumber.com/en/steel_composit ion_eu.php?name_id=1507 (Accessed: 22.06.2017).

5. (2017) EN-GJS-500-7, Ductile Cast Iron GGG50. Available: http://www.iron- foundry.com/en-gjs-500-7-ductile-cast-ironggg50.html (Accessed: 22.06.2017).

6. Richardson I (2016) Guide to Nickel Aluminium Bronze for Engineers. Copper Development Association. 98 p.

7. (2017) C85700. Available: http://www.concast.com/c85700.php (Accessed: 22.06.2017).

8. (2017) Cast aluminium properties. Available: http://www.alteams.com/alteams-techcentre/design-assistance/cast-aluminiumproperties.html (Accessed: 22.06.2017).

9. (2017) ZINC ALLOY \#ZA27. Available: http://zinc.purityzinc.com/item/zinc-alloys/zincalloy-za27/item-1019 (Accessed: 22.06.2017). 